\title{
Enzymatic Hydrolysis of Alkaline Pretreated Coconut Coir
}

\author{
Akbarningrum Fatmawati ${ }^{\text {* }}$, Rudy Agustriyanto ${ }^{1}$, Yusnita Liasari ${ }^{2}$ \\ ${ }^{1}$ Department of Chemical Engineering, Surabaya University, Jl. Raya Kalirungkut, \\ Surabaya 60292, Indonesia \\ 2 Biotechnology Faculty, Surabaya University, Jl. Raya Kalirungkut, \\ Surabaya 60292, Indonesia
}

Received: 2nd October 2012; Revised: 31st January 2013; Accepted: 6th February 2013

\begin{abstract}
The purpose of this research is to study the effect of concentration and temperature on the cellulose and lignin content, as well as the reducing sugars produced in the enzymatic hydrolysis of coconut coir. In this research, the coconut coir is pretreated using $3 \%, 7 \%$, and $11 \% \mathrm{NaOH}$ solution at $60{ }^{\circ} \mathrm{C}, 80{ }^{\circ} \mathrm{C}$, and $100{ }^{\circ} \mathrm{C}$. The pretreated coir were assayed by measuring the amount of cellulose and lignin and then hydrolysed using Celluclast and Novozyme 188 under various temperature $\left(30{ }^{\circ} \mathrm{C}, 40{ }^{\circ} \mathrm{C}, 50{ }^{\circ} \mathrm{C}\right)$ and $\mathrm{pH}(3,4,5)$. The hydrolysis results were assayed for the reducing sugar content. The results showed that the alkaline delignification was effective to reduce lignin and to increase the cellulose content of the coir. The best delignification condition was observed at $11 \% \mathrm{NaOH}$ solution and $100{ }^{\circ} \mathrm{C}$ which removed $14.53 \%$ of lignin and increased the cellulose content up to 50.23\%. (C) 2013 BCREC UNDIP. All rights reserved. (Selected Paper from International Conference on Chemical and Material Engineering (ICCME) 2012)
\end{abstract}

Keywords: coconut; enzyme; hydrolysis; lignocellulose

How to Cite: Fatmawati, A., Agustriyanto, R., Liasari, Y. (2013). Enzymatic Hydrolysis of Alkaline Pretreated Coconut Coir. Bulletin of Chemical Reaction Engineering \& Catalysis, 8 (1): 34-39

(doi:10.9767/bcrec.8.1.4048.34-39)

Permalink/DOI: http://dx.doi.org/10.9767/bcrec.8.1.4048.34-39

\section{Introduction}

The lignocellulosic biomass is represented by the high-level crop, hard wood and soft wood with cellulose, hemicellulose and lignin as the main component. One of the lignocellulosic biomass available in Indonesia is coconut coir. Coconut productivity in Indonesia is very high, reaching 15.5 billion coconuts per year, which is equivalent to 3.02 million tons of copra, 3.75 million tons of water, 0.75 million tons of shell, 1.8 million tons of coir fiber, and 3.3 million tons of coir dust. The co-

* Corresponding Author. (A. Fatmawati)

E-mail: akbarningrum@ubaya.ac.id

Tel: +62-31-2981158, Fax: +62-31-2981158 conut processing industries are still largely focused on coconut meat processing, while the process industry of its byproducts such as coconut water, coconut coir and coconut shell is still in small scale and traditional [1]. However, the potential of the byproduct is very large, especially the coconut coir.

Coconut coir is composed of cellulose, lignin, pectin, hemicellulose, and ash. Cellulose can be processed and converted into alternative energy sources such as ethanol, and biohydrogen via fermentation. In order to utilize the cellulose for fermentation substrate, it must be hydrolyzed either chemically or enzymatically to produce sugar.

Cellulose is the b-1,4-polyacetal of cellobiose which is a polymer of glucose. This cellulose mole- 
cule is a long straight chain and hydrogen bonds are formed between cellulose molecules. This makes the formation of a compound that is comprised of several parallel chains attached to each other called microfibrils which in turn are united into fibres. There are crystalline and noncrystalline region in the cellulose microfibrils. Lignin is an amorphous three dimensional polymer with polyphenols units as the predominant monomers. The most commonly found are p-coumaryl alcohol, coniferyl alcohol and sinapyl alcohol. The bond between cellulose, hemicellulose and lignin includes ether, ester and hydrogen bonds [2]. Lignin is a component of coconut coir that is rigid and prevent the cellulose degradation [3].

Pretreatment is an important process in attempt to degrade cellulose to produce sugar. This prosess is intended to alter the cellulose structure so that it will be accessible for hydrolytic enzymes. The lignin degradation is necessary to increase the rate of the hydrolysis of lignocellulosic materials. This can be done by physical, chemical, and biological method. One method of chemical delignification is pretreatment using several kinds of alkaline solutions such as $\mathrm{NaOH}$ and $\mathrm{Ca}(\mathrm{OH})_{2}$ [2]. The delignification can be carried out using $\mathrm{NaOH}$ solution that can attack the structure of lignin and disrupt the crystalline structure of cellulose [2]. The delignification of coconut coir using acidic condition has been investigated [4]. This research studied the alkaline pretreatment using $\mathrm{NaOH}$ solution and the enzymatic hydrolysis of coconut coir. $\mathrm{NaOH}$ is relatively cheap, easily obtained and also more soluble in water than $\mathrm{Ca}(\mathrm{OH})_{2}[5]$.

\section{Materials and Method}

\subsection{Materials and Instrumentations}

The coconut coir was soaked for 24 hours, then washed using flowing water for 1 hour and dried. The dried coconut coir was cut $( \pm 5 \times 5 \mathrm{~cm})$, and then milled using a disc mill (FFC type $23 \mathrm{~A}$, with a speed of $5800 \mathrm{rpm}$, power $3 \mathrm{~kW}$, Shandong Ji Mu Disk Mill Machinery). Finally, it was sieved (Retsch 5657 test sieve, no. mesh 40, a hole the size of $0.425 \mathrm{~mm}$, stainless steel, W Haan, Germany) to obtain the particle size of 40 mesh.

\subsection{Alkaline Pretreatment}

In this study, the delignification was performed using various concentration of $\mathrm{NaOH}(3 \%, 7 \%$ and $11 \%$ ) and temperature of $60^{\circ} \mathrm{C}, 80^{\circ} \mathrm{C}$ and $100^{\circ} \mathrm{C}$. The coconut coir loading was 15 grams in $200 \mathrm{ml}$ solution of $\mathrm{NaOH}$. The pretreatment process was conducted in a reactor equipped with reflux for 60 minutes. After alkaline treatment, the slurry was filtered and then neutralized using distilled water and dried. Subsequently, the dried solid was tested for the content of lignin and cellulose. The experiment was done in duplicate.

\subsection{Enzymatic Hydrolysis}

Enzymatic hydrolysis was done using endoglucanase enzymes (Cellulase, Trichoderma reesei ATCC 26 921, Sigma Aldrich) and B-glucosidase (Cellobiase, Aspergillus niger, Sigma Aldrich). The cellulase enzyme loading used was $15 \mathrm{FPU} / \mathrm{g}$ cellulose while the cellulase to cellobiase ratio was 2 FPU/CBU. The operating condition of hydrolysis process was maintained at temperature of $40^{\circ} \mathrm{C}$, $50^{\circ} \mathrm{C}, 60^{\circ} \mathrm{C}$ and $\mathrm{pH}$ of $3,4,5$ using $0.05 \mathrm{M}$ citrate buffer. The hydrolysis was carried out for 2 grams of solids in $50 \mathrm{ml}$ of citrate buffer solution in an incubator shaker (GFL brands 3032 models) at a speed of $90 \mathrm{rpm}$ for 72 hours.

This enzymatic reaction was stopped by heating at $100{ }^{\circ} \mathrm{C}$ in a waterbath for 5 minutes. Filtration was then performed using filter paper and the reducing sugar content of the filtrate was analyzed.

\subsection{Chemical Analysis}

In this study, the analysis of cellulose and lignin content was conducted by Chesson method [6]. The reducing sugar content analysis performed by the method of DNS (Dinitrosalicylic Acid) [7].

\section{Results and Discussion}

The raw of coconut coir contained $41.70 \%$ of cellulose and $30.54 \%$ of lignin. After delignification, it was observed that the cellulose content increased to the range of $45.39 \%-50.23 \%$, while the lignin decreased to the range of $26.10 \%-29.28 \%$. This experimental works was repeated twice and the chemical analysis of each experiment was also repeated twice. The maximum error was $3.27 \%$.

\subsection{Effect of Delignification Temperature and $\mathrm{NaOH}$ Concentration on Cellulose Con- tent of Coconut Coir}

Many factors could affect the cellulose content of the pretreated coconut coir. The two of them were temperature and concentration of $\mathrm{NaOH}$ solution which could be seen in Figure 1.

The cellulose content of the coconut coir increased with the delignification temperature. The delignification using $3 \% \mathrm{NaOH}$ solution at $60{ }^{\circ} \mathrm{C}$ gave the lowest cellulose content. The cellulose content increased by increasing concentration of $\mathrm{NaOH}$ solution. As seen in Figure 1, the delignifi- 


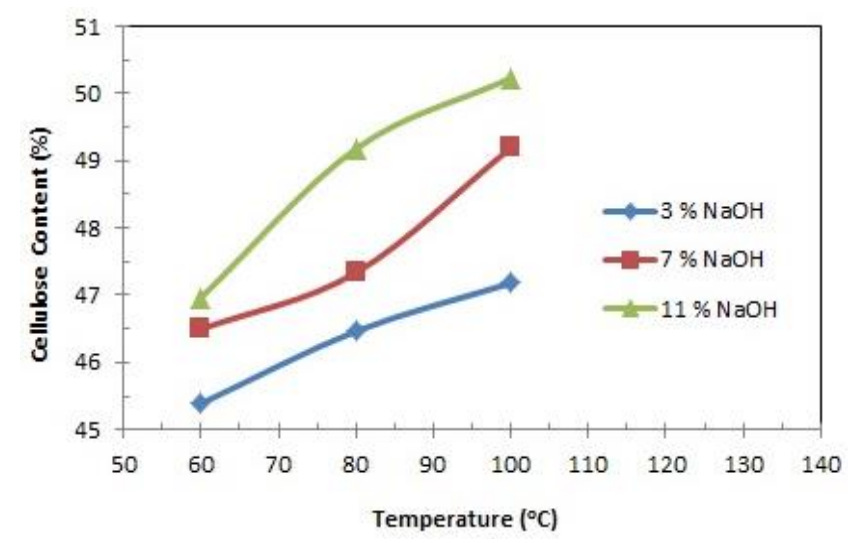

Figure 1. The Cellulose content of the coconut coir after delignification

cation at $60^{\circ} \mathrm{C}$ resulted in the highest cellulose content at $11 \% \mathrm{NaOH}$ solution.

Figure 1 shows that the pretreatment using alkaline solution at various temperature and concentration could affect the cellulose content in coconut coir. This was caused by various reactions occurred during delignification.

\subsection{Effect of Delignification Temperature and $\mathrm{NaOH}$ Concentration On Lignin Content of Coconut Coir}

The lignin content of pretreated coconut coir was also affected by temperature and concentration of $\mathrm{NaOH}$ solution, as shown in Figure 2.

At $\mathrm{NaOH}$ concentrations of $3 \%, 7 \%$, and $11 \%$, the remaining lignin content at delignification temperature of $60^{\circ} \mathrm{C}$ was higher than that at $80^{\circ} \mathrm{C}$. The lowest remaining lignin content was observed at delignification temperature of $100^{\circ} \mathrm{C}$ for a all concentration of $\mathrm{NaOH}$. The remaining lignin content in the coconut coir decreased with temperature.

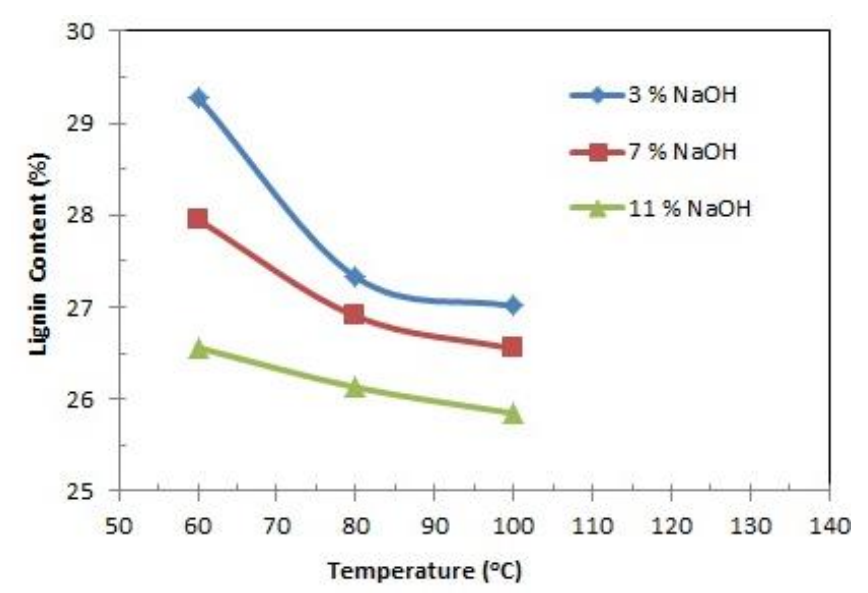

Figure 2. Lignin content of the coconut coir after delignification
The variation of concentration also gave the same effect to lignin content of the coconut coir. The higher concentration of $\mathrm{NaOH}$ the lower the lignin content of the coconut coir.

As seen in Figure 1 and Figure 2, effect of $\mathrm{NaOH}$ concentration and temperature on the lignin concentration was in the contrary with that on the cellulose concentration. The presence of alkaline $(\mathrm{NaOH})$ solution could degrade the lignin content of coconut coir. This degradation (delignification) reaction could be enhanced by increasing alkaline concentration and reaction temperature. Therefore, the lignin concentration decreased while the cellulose concentration increased with alkaline concentration and reaction temperature.

The correlations of delignification temperature and with the remaining lignin content of coconut coir can be explained using the Arrhenius theory as shown in Equation 1 and the reaction rate equation in Equation 2.

$$
\begin{gathered}
k=k_{o} \cdot e^{-\frac{E a}{R T}} \\
-r_{A}=k \cdot C^{n}
\end{gathered}
$$

where: $-r_{A}:$ the rate of reaction; $k:$ reaction rate constant; $C$ : concentration; $T$ : temperature; and $n$ : reaction order.

According to the above equation, the higher the temperature, the greater the value of the reaction rate constant $(k)$ would be. Therefore, at the same concentration $(C)$, the rate of reaction $\left(-r_{A}\right)$ would increase. Similarly, at the same temperature $(T)$, if the concentration $(C)$ increased, the rate of reaction would also rise. The increased of the reaction rate would speed up the process of lignin removal, and hence more lignin would be removed and more cellulose would be obtained.

Silverstein et al. reported that the dilute $\mathrm{NaOH}$ pretreatment has removed at $7.28 \%-14.301 \%$ lignin content from cotton stalk at $30 \mathrm{~min}$ reaction and temperature of $90^{\circ} \mathrm{C}$ using $\mathrm{NaOH}$ concentration of $0.5-2 \%$ [8]. In this research, the lignin content removal ranged from $4.096 \%$ to $14.55 \%$.

\subsection{Reducing Sugar Content of the Hydroly- sate}

The raw coconut coir was hydrolyzed under the same condition as pretreated coconut coir, which was at temperature of $50^{\circ} \mathrm{C}$ and $\mathrm{pH}$ 4. This hydrolysis resulted in $0.171 \mathrm{~g} / \mathrm{L}$ reducing sugar. The 
same step was carried out to the pretreated coconut coir. The reducing sugar content obtained were varied depending on the variation of temperature and concentration of $\mathrm{NaOH}$ solution, as shown in Table 1. As shown in Table 1, it could be concluded that the delignification could increase the reducing sugar content of coconut coir.

\subsection{Effect of $\mathrm{NaOH}$ Concentration on the Sug- ar Production}

The reducing sugar of coconut coir hydrolysate was affected by the concentration of $\mathrm{NaOH}$ solution. In the hydrolysis process at temperature of 50 ${ }^{\circ} \mathrm{C}$ and $\mathrm{pH} 4$, the result is presented in Figure 3.

Table 1. Reducing sugar of the pretreated coconut coir

\begin{tabular}{|c|c|c|}
\hline \multicolumn{2}{|c|}{ Delignification Condition } & \multirow{2}{*}{$\begin{array}{c}\text { Reducing } \\
\text { Sugar } \\
\text { (gr/L) }\end{array}$} \\
\hline $\begin{array}{c}\text { Concentration } \\
\text { of } \mathrm{NaOH}(\%)\end{array}$ & $\begin{array}{c}\text { Temperature } \\
\left({ }^{\circ} \mathrm{C}\right)\end{array}$ & \\
\hline \multirow{3}{*}{3} & 60 & 1.85 \\
\hline & 80 & 4.23 \\
\hline & 100 & 4.67 \\
\hline \multirow{3}{*}{7} & 60 & 2.94 \\
\hline & 80 & 5.58 \\
\hline & 100 & 5.80 \\
\hline \multirow{3}{*}{11} & 60 & 4.53 \\
\hline & 80 & 6.18 \\
\hline & 100 & 7.57 \\
\hline
\end{tabular}

\subsection{Effect of Delignification Temperature on the Sugar Production}

Beside the concentration of $\mathrm{NaOH}$ solution, the temperature of delignification also affected the production reducing sugar in the hydrolysis, as shown in Figure 4.

At delignification temperature of $60^{\circ} \mathrm{C}$ with various $\mathrm{NaOH}$ concentration, the reducing sugar obtained was the lowest among the other conditions. The highest reducing sugar was obtained from the coir delignified at temperature of $100^{\circ} \mathrm{C}$. The result showed that the higher the temperature of delignification the more effective the enzymatic hydrolysis would be. This phenomena was due to the higher the temperature of delignification, the higher the levels of available cellulose produced, and hence the more available substrate for enzyme would be obtained. This would resulted in higher concentration of reducing sugar produced.

\subsection{Effect of Hydrolysis pH on the Reducing Sugar Production}

After the best condition of delignification process was obtained, the experiment was continued to enzymatic hydrolysis at temperature of $50^{\circ} \mathrm{C}$ with variation of $\mathrm{pH} 3$ and 5 . The reducing sugar produced is shown in Figure 5.

The highest reducing sugar was obtained in the hydrolysis at $\mathrm{pH}$ 4. At $\mathrm{pH} 5$, the reducing sugar produced was slightly lower than that at $\mathrm{pH} 4$, and the lowest one was obtained at $\mathrm{pH} 3$. The optimum $\mathrm{pH}$ of hydrolysis in this research was observed at

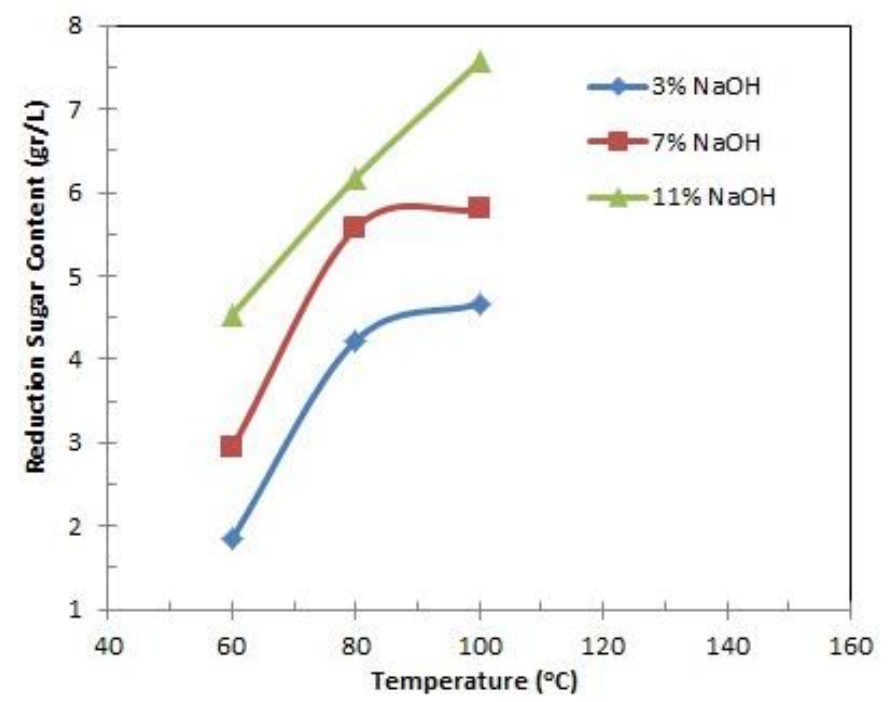

Figure 3. The reducing sugar content at various concentration of $\mathrm{NaOH}$ solution

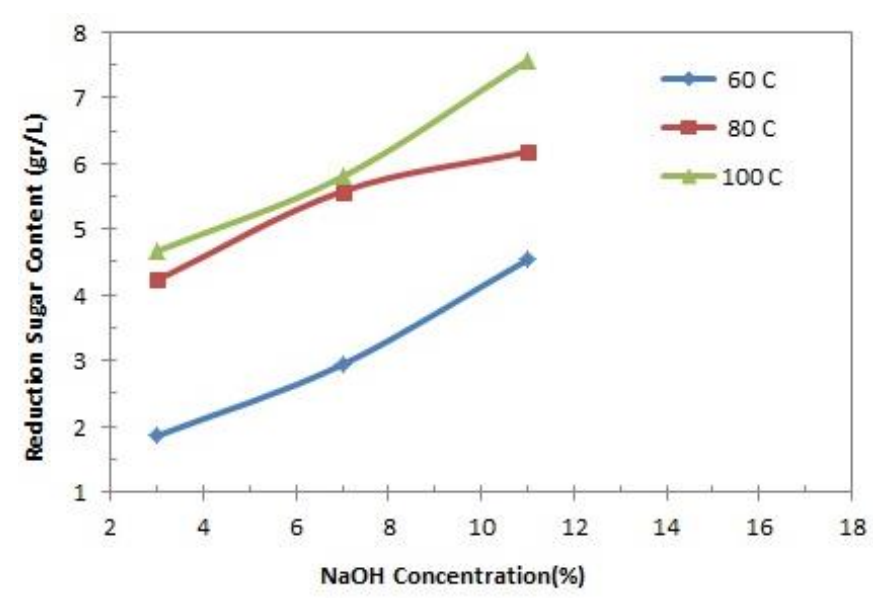

Figure 4. The reducing sugar content at various temperature of enzymatic hydrolysis 
about 4 and 5 .

The change of $\mathrm{pH}$ could affect the enzyme activity by changing the structure or the charge of the active site of enzyme. At the optimum $\mathrm{pH}$, there was charge suitability between the enzyme and the substrate, so the substrate was exactly placed in the active site of enzyme. Those enzyme and substrate then formed enzyme-substrate complex and produced products. At $\mathrm{pH}$ lower than the optimum, the substrate lost its negative charge. The enzyme could not bind the substrate at higher $\mathrm{pH}$ because it was ionized and lost its positive charge [9].

\subsection{Effect of Hydrolysis Temperature on the Sugar Production}

After the best $\mathrm{pH}$ of hydrolysis was observed ( $\mathrm{pH} 4)$, the hydrolysis process was continued at various temperature $\left(40^{\circ} \mathrm{C}\right.$ and $\left.60^{\circ} \mathrm{C}\right)$. The reducing

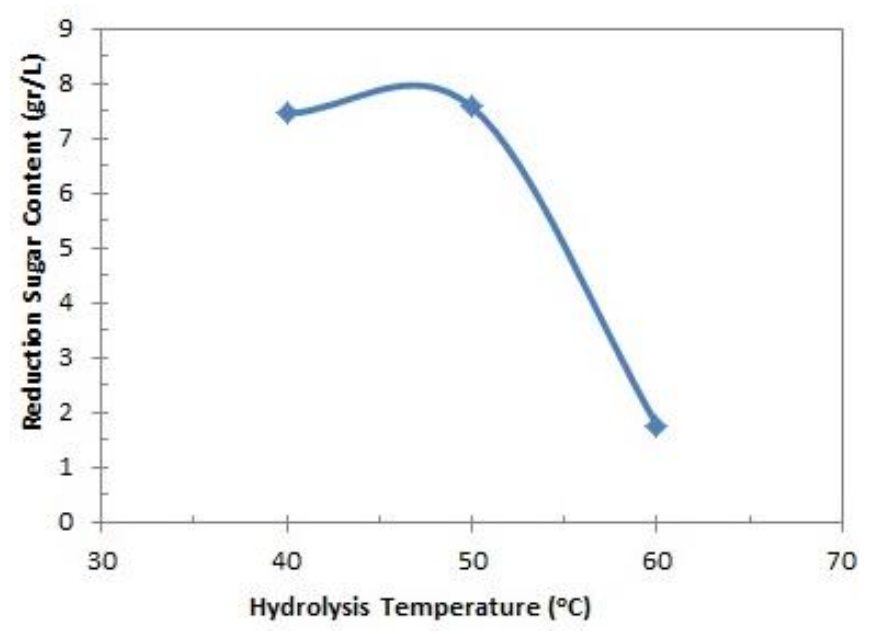

Figure 6. The Reducing Sugar Content at Various Temperature of Enzymatic Hydrolysis

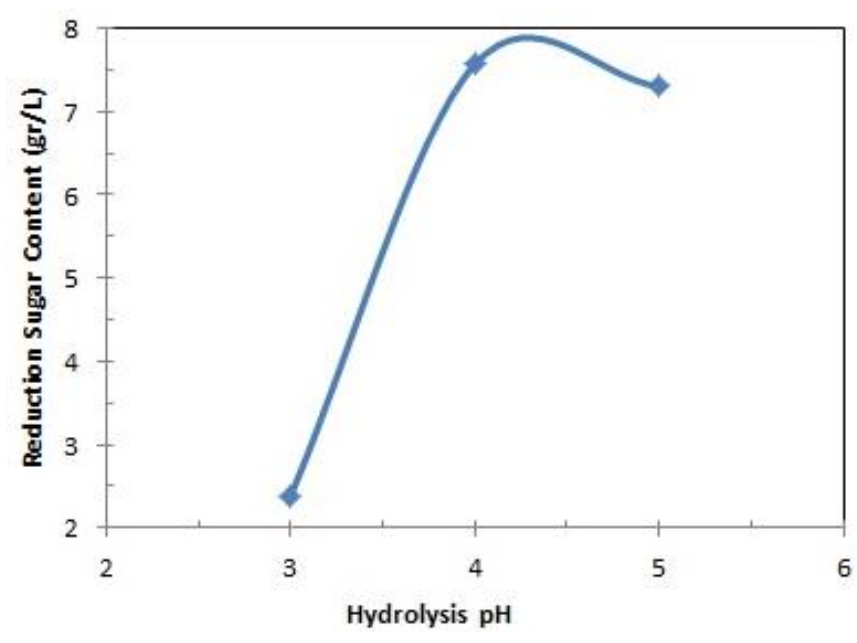

Figure 5. The Reducing Sugar Content at Various $\mathrm{pH}$ of Enzymatic Hydrolysis sugar obtained at this operating condition was shown in Figure 6.

The hydrolysis at $\mathrm{pH} 4$ and temperature of $40^{\circ} \mathrm{C}$ resulted in the reducing sugar concentration slightly lower than that which carried out at temperature of $50^{\circ} \mathrm{C}$. At temperature of $60^{\circ} \mathrm{C}$, the reducing sugar concentration was lower significantly than those obtained at temperature of $50^{\circ} \mathrm{C}$ and $40^{\circ} \mathrm{C}$. In other words, the highest reducing sugar was observed from hydrolysis at $\mathrm{pH} 4$ and temperature of $50^{\circ} \mathrm{C}$. The optimum hydrolysis temperature seemed to occur at temperature between 40$50^{\circ} \mathrm{C}$. This could be concluded from the difference of reducing sugar produced from hydrolysis at $50^{\circ} \mathrm{C}$ and $40^{\circ} \mathrm{C}$, where they were only slightly different. This behavior might be due to a hydrolysis temperature range between $40-50^{\circ} \mathrm{C}$ which was close to the optimum temperature of the enzyme. The enzyme was almost reached its optimal activity and the reducing sugar produced did not differ significantly or nearly constant. This followed by the biochemical theory which stated that the thermal denaturation of the enzyme as a type of protein could occur at temperature of $45-50^{\circ} \mathrm{C}$. At above temperature of $50^{\circ} \mathrm{C}$ the enzyme gradually became inactive due to denatured protein [10].

The influence of delignification conditions on this research result is depicted in Figures 7 to 9. In those figures the experimental data (shown in asteriks) were presented along with the result from surface models. It can be concluded from those figures that the best condition for coconut coir delignification condition is at $11 \% \mathrm{NaOH}$ concentration and temperature of $100^{\circ} \mathrm{C}$.

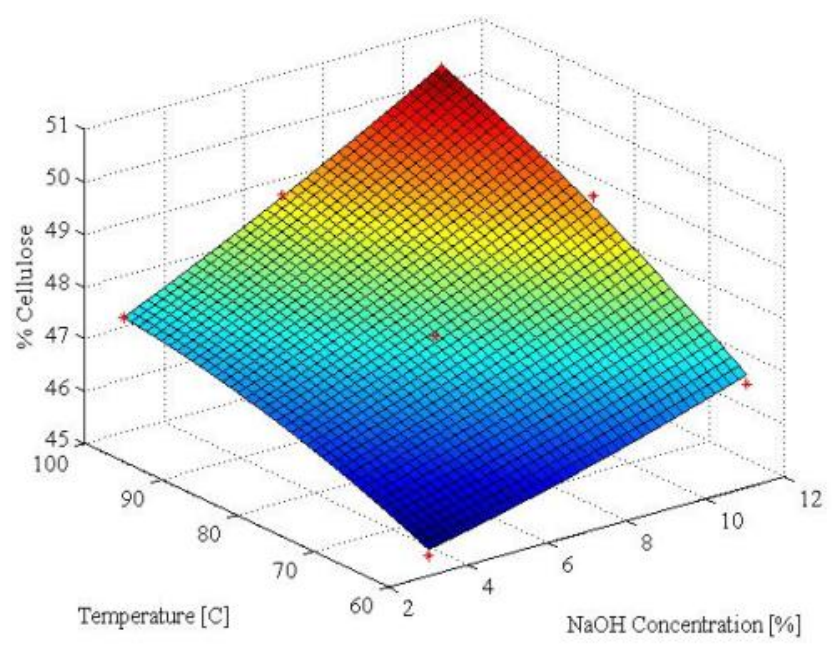

Figure 7. The effect of delignification condition on the cellulose content of coconut coir 


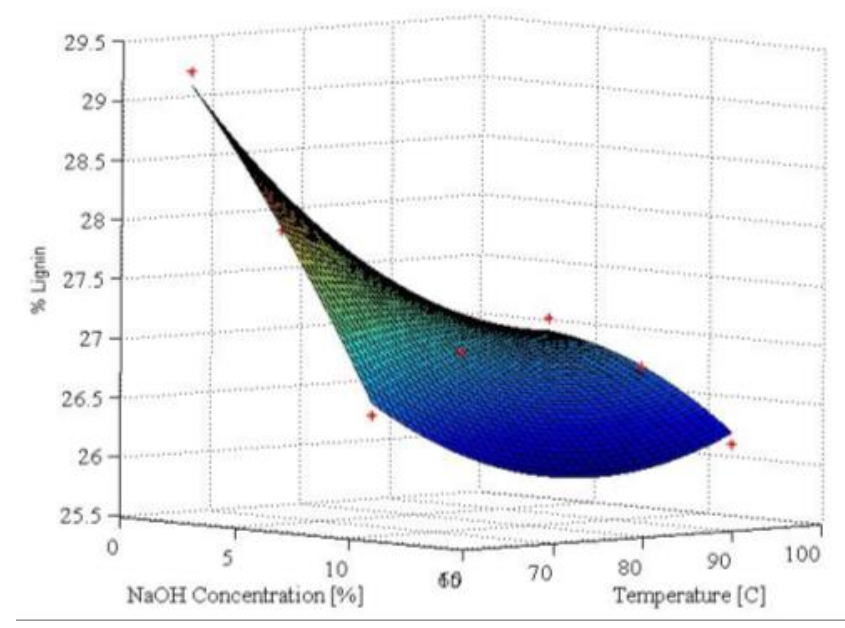

Figure 8. The effect of delignification condition on the lignin content of coconut coir

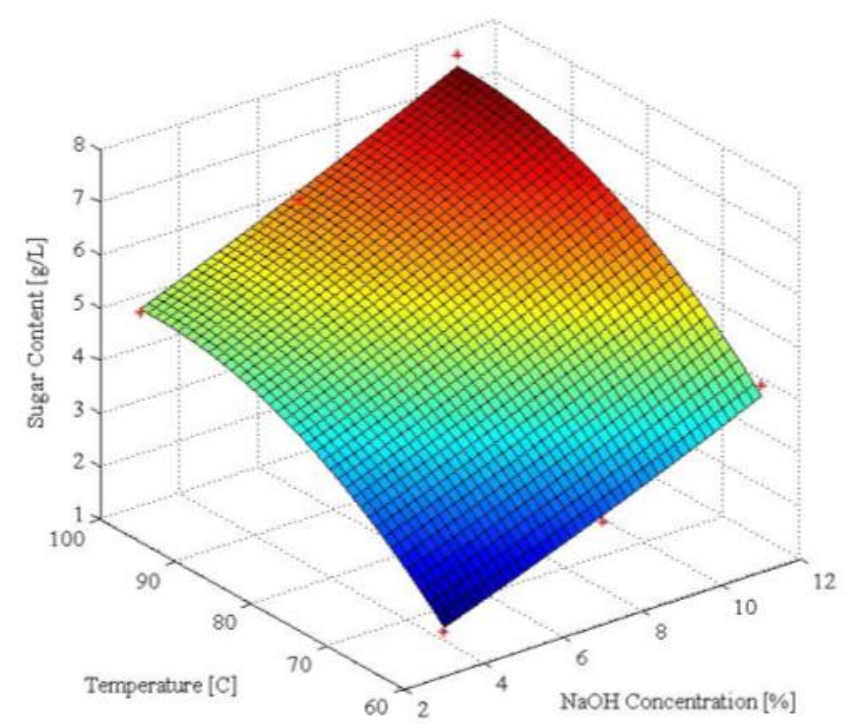

Figure 9. The effect of delignification condition on the sugar content of the hydrolysate

\section{Conclusions}

The delignification of coconut coir using dilute $\mathrm{NaOH}$ solution was effective to reduce lignin content and increase cellulose content of the coconut coir. The increasing temperature and concentration of $\mathrm{NaOH}$ would increase the amount of lignin removed, and hence as well as reducing sugars produced. The best condition of the delignification process was observed at $11 \% \mathrm{NaOH}$ solution and delignification temperature of $100^{\circ} \mathrm{C}$ which removed $14.53 \%$ of lignin content and increased the cellulose content up to $50.23 \%$. The maximum reducing sugar concentration that could be achieved was $7.57 \mathrm{~g} / \mathrm{L}$.

\section{Acknowledgement}

The authors gratefully acknowledge Surabaya University for facilitating this work. The authors would also like to thank Caroline adhelia and Jovita Paulina for their laboratory work support.

\section{References}

[1] Tim Badan Penelitian dan Pengembangan Pertanian. 2005. Prospek dan Arah Pengembangan Agribisnis Kelapa. Departemen Pertanian, Jakarta.

[2] Harmsen, P.F.H., Huijgen, W.J.J., Lopez, L.M.B., Bakker, R.R.C. (2010). Literature Review of Physical and Chemical Pretreatment Processes for Lignocellulosic Biomass. Biosynergy.

[3] Rajan, A., Senan, R.C., Pavithran, C., Abraham, T.E. (2005). Biosoftening of Coir Fiber Using Selected Microorganisms. Bioprocess and Biosystem Engineering, 28: 165-173.

[4] Agustriyanto, R., Fatmawati, A., Liasari, Y. (2012). Study of Enzymatic Hydrolysis of Dilute Acid Pretreated Coconut Husk. Bulletin of Chemical Reaction Engineering \& Catalysis, 7(2): 137141.

[5] Green, D.W., Perry, R.H. (2008). Physical Properties of Pure Substances. In Perry's Chemical Engineers' Handbook 8th Ed. The McGraw-Hill Companies, Inc., New York, p.2-11, 2-14.

[6] Datta, R. (1981). Acidogenic Fermentation of Lignocellluose-Acid Yield and Convertion of Component. Biotechnology and Bioengineering. 23: 21672170.

[7] Miller, G.L. (1959). Use of Dinitrosalicylic Acid Reagent for Determination of Reducing Sugar. Analytical Chemistry 31: 426-428.

[8] Silverstein, R.A., Chen, Y., Sharma-Shivappa, R., Boyette, M.D., Osborne, J. (2007). A Comparison of Chemical Pretreatment Methods for Improvement of Saccharification of Cotton Stalks. Bioreseource Technology 98: 3000-3011.

[9] Murray, R.K., Granner, D.K., Mayes, P.A., Rodwell, V.W. (2000). Harper's Biochemistry 25th Ed. Appleton and Lange, USA.

[10] Lee, J.M. (1992). Biochemical Engineering. Prentice-Hall International, Inc., New Jersey. 